\title{
STUDI KASUS PRASANGKA DALAM PRAKTEK KONSELING MULTIBUDAYA MAHASISWA BK
}

\author{
Elia Firda Mufidah \\ Universitas PGRI Adi Buana Surabaya \\ eliafirda@unipasby.ac.id
}

\begin{abstract}
Abstrak
Konseling multibudaya menjadi hal yang akan dihadapi konselor ketika melakukan konseling dengan individu yang berbeda-beda dari setiap konseli. Hal tersebut memunculkan prasangka yang seharusnya bisa dikendalikan oleh calon konselor atau mahasiswa bimbingan dan konseling ketika melakukan praktek konseling multibudaya di lapangan. Tujuan penelitian ini mendiskripsikan bagaimana munculnya prasangka ketika mahasiswa melakukan konseling multibudaya. Penelitian ini menggunakan penelitian kualitatif study kasus dengan 4 subjek penelitian. Hasil dari penelitian memaparkan bahwa mahasiswa ketika melakukan konseling multbudaya masih memunculkan prasangka.
\end{abstract}

Kata Kunci : Prasangka, Konseling Multibudaya, Mahasiswa BK

\section{PENDAHULUAN}

Pernyataan dalam salah sau rambu aturan pelaksanaan bimbingan dan konseling (2007) menjasakan bahwa salah satu kompetensi konselor harus memilik integritas dan stabilitas dalam kepribadiannya untuk peka, berempati dan menghrmati keberagaman yang ada. Hal tersebut menyiratkan adanya tuntutan untuk memiliki sensitifitas budaya. Diharapkan dari sesitifitas yang dimilikii membuat konselor mampu memahami setiap konselinya. Pemahaman yang benar akan diperoleh layanan yang efektif dan efisien untuk menunjang penyelesaian tugas perkembangan setiap konseli.

Kata budaya adalah kata yang multidimensi. Multibudaya berakar dari konsep budaya. Sehingga multibudaya bermakna pertemuan antara beberapa budaya. Manusia merupakan individu yang selalu berinteraksi dengan lingkungannya. Lingkungan membawa budaya yang menjadi ciri. Individu yang merupakan salah satu komponen dalam lingkungan tentunya memiliki budayanya sendiri-sendiri. Hal tersebut terjadi karena individu memiliki etnografik, demografik dan status sendiri-sendiri. Individu yang tinggal disuatu tempat akan berbeda dengan tempat lain. Baik dalam hal 
berbicara maupun berpakaian. Begitu pula individu yang lahir dari sebuah keluarga akan berbeda dengan individu yang lahir dari keluarga lainnya. Hal itu terjadi karena iklim pendidikan dalam keluarga yang berbeda.

Perbedaan-perbedaan tersebut yang menjadi ciri masing-masing individu. Dalam proses konseling tentunya antara konselor dan konseli terjadi perbedaan budaya yang mengarah kepada terjadinya konseling multibudaya. Konseling multibudaya mengajarkan kepada individu untuk bisa menghargai perbedaan yang dimiliki dari sisi konseli maupun konselor karena danya proses konstruk yang berbeda dari perjalanan masing-masing indvidu baik konselor maupun konseli. Oleh sebab itu dibutuhkan kepekaan juga dalam konseling multibudaya ang meliputi kepekaan dalam hal nilai budaya, pendangan hidup dan strategi atau intervensi yang tepat (Nugraha dan Sulistiana, 2017)

Konselor diharapkan ketika melakukan konseling memahami hal ini. Setiap konseli tentnya memiliki ketidaksamaan budaya. Konselor diharapkan mampu memiliki sifat unconditional positive regard atau sebuah konsep penerimaan tak bersyarat terhadap setiap konseli. Penerimaan tak bersayarat mengarahkan kepada penerimaan terhadap perbedaan yang ada disetiap konseli. Perbedaan tersebut terjadi karena proses konstruktif atau pengolahan informasi dari setiap individu yang berbeda. Proses pegolahan tersebut membentuk sebuah pengetahuan maupun skema berpikir yang berbeda dari setiap individu. Seperti halnya konseli A ketika menghadapi ujian memiliki konstruk bahwa ujian merupakan hal yang biassa dan tidak perlu dikhawatirkan maka yang terjadi adalah konseli tersebut bisa lancar dalam menghadapi ujian. Sebaliknya pada konseli B memiliki konstruk berbeda terhadap ujian. Konseli B mengkonstruk ujian sebagai hal yang menakutkan. Maka yang terjadi adalah ketidaksapan dalam menghadapi ujian. Muncullah gejala-gejala psikosmatis dalam diri konseli B. Semua itu berlandasakn dari paham konstutruktivisme.

Konstruktivisme mengarah kepada proses belajar dimana pembentukan pengetahuan dilakukan sendiri oleh orang tersebut melalui pengalaman yang mereka lakukan secara realitas (Abimayu, 2008). Sehingga konstruktive memiliki anggapan bahawa pengetahuan merupakan hasil dari konstruksi manusia. Manusia mengkonstruk pengetahuan yang dimiliki melalui interaksi atau hubungan dengan individu diluar diriya. Bisa juga hal dengan lingkungan maupun objek lain yang ada disekitarnya. Pemrsesan pengatahuan dari pengalaman membutuhkan kemampuan dalam mengingat dan mengungkapkan kembali apa yang dialami kemudian membandingkan dan mengambil keputusan dari apa yang sudah terjadi.

Ketika individu melakukan proses konseling tentunya mereka akan membawa budayanya masing-masing. Keefektifan proses konseling bergantung pada banyak faktor. Salah satu faktor utama yang menentukan adalah relasi atau hubungan antara konselor dan konseli. Banyak kendala ketika konseling multibudaya dilakukan. Ketika setiap individu melakukan konstruktivitas terhadap budaya yang masuk ke dalam dirinya, maka akan timbul berbagai penafsiran. Salah satunya adalah timbullah prasangka.

Persangka timbul dimulai ketika sebuah penilaian timbul tanpa buktibukti yang kuat dan mendukung. Hal tersebut sesuai dengan asal mula kaat prasangka yang menggabungkan 2 kata prae dan judicium yang bermakna 
sebeluum keputusan (Hogg, 2002). Selain itu, prasangka merupakan proses penilaian yang diberikan seseorang tanpa melalui pemeriksaan terlebih dahulu (Chambers English Dctionary, dalam Brown, 2005). Prasangka juga merupakan suatu sikap sosial yang merendahkan atau mengarah kepada keyaknan kognitif yang negatif dari suatu kelompk kepada kelompok lainnya (Hog, 2002). Prasangka sudah seharusnya dihindari konselor dalam proses konseling untuk memperlancar proses konseling sehingga menghasilkan suatu penyelesaian permasalahan yang baik.

\section{METODE}

Penelitian yang dilakukan peneliti menggunakan acuan penelitian kualitatif studi kasus. Bogdan dan Taylor (Moloeng, 2011) menjelaskan bahwa penelitian kualitatif merupakan suatu prosedur yyag mengjaslkan data deskriptif berupa kata tertulis atau lisan yang bersumber dari perilaku yang diamati. Penelitian ini mengarah kepada munculnya latar individu yang holistic ataupun utuh. Shaughnessy (2007) menjelaskan penelitian studi kasus adalah titik awal untuk peneliti yang mulai memasuk bidang penelitihan yang masih relative sedikit diketahui. Penelitian ini dilakukan di beberapa sekolah negeri yang digunakan sebagai tempat magang mahasiswa prodi Bimbingan dan Konseling Universitas PGRI Adi Buana Surabaya. Subjek penelitian terdiri dari 4 yang berasal dari mahasiswa yang melakukan magang di sekolah dan sudah menempuh matakuliah syarat untuk melakukan magang.

Penelitian ini menggunakan wawancara semi terstruktur. Wawancara semi terstruktur mengacu kepada topik pertayaan yang sebelumnya sudah ditentukan oleh peneliti untuk semua responden. Pada bagian-bagian tertentu dirancang juga pertanyaan lain yang memungknkan responden untuk menjelaskan pengalaman dan pengetahuannya. Peneliti melakukan wawancara kepada mahasiswa program studi bimbingan dan konseling dengan mewawancarai mahasiswa terkait pengalamannya ketika praktek melakukan konseling dengan konseli yang sesungguhnya sehingga menimbulkan prasangka dalam proses konseling.

Observasi pada penelitian ini menggunakan observasi non partisian. Menurut Bogdan (Sugiono, 2012) menjelaskan data pribadi kehidupan di masa kecil, di sekolah, masyarakat atau sutobografi akan membantu meningkatkan kredibilitas hasil penelitian. Ppenelitian ini menggunakan teknik analisis data tematik yang mengarah kepada tema-tema yang menonjol ari kategori dalam tujuan penelitian (Hanurawan, 2012).

\section{HASIL DAN PEMBAHASAN}

Implementasi konseling multibudaya tidak hanya ditekankan pada pemahaman konselor terhadap budaya konselinya. Tetapi sudah masuk dalam teori dan teknik yang dipakai konselor dalam menangani masalah konselinya. Diperlukan pemahaman yang khusus dari konselor agar proses konseling bisa berjalan dengan lanncar meskipun antara konselor dan konseli memiliki budaya yang berbeda. Konsling multibudaya memberikan landasan kepada konselor untuk memberikan layanan kepada konseli. Menurut Peterson, dkk (2002) kesadaran multibudaya bukan lagi menjadi perhatian khusus dari konselor, tapi sudah menjadi kompetensi dasar bagi konselor dalam konseling multibudaya. 
Kompetensi konselin multibudaya meliputi beberapa hal yakni sikap, pengetahuan, keterampilan yang dimiliki konselor (Sue, dkk., 1996). Selain itu, konselor haruslah memiliki kerangka kerja yang konseptual dalam melakukan konseling multibudaya. Kerangka kerja konseptual tersebut meliputi kompetesi budaya yang menunjukkan sebuah kapasitas dalam hal bias individu, keyakinan dari konselor terhadap beberapa aspek budaya baik secara gender maupun budayanya yang dimiliki. Kemudian konselor sebaiknya memiliki pandangan yang luas terkait budaya disekitar. Konselor sebaiknya juga memiliki keterampilan yang lebih dalam melakukan asesment dan evaluasi serta implementasi dari teori konseling untuk membantu setiap konseli yang berbeda (Sue, dkk., 1996)

Selain itu, Holcom-McCoy (dalam Dollarhide, dkk., 2008) juga memaparkan tentang kompetensi yang dibutuhkan konselor ketika melakukan konseling multibudaya di sekolah. Kompetensi tersebut terdiri dari memahami strategi dan pendekatan konseling yang sesuai, memiliki pengetahuan terkait proses konsultasi, pemahaman terhadap rasisme dan resistensi pada siswa, memahami identitas individu, memahami proses asemsmen, memahami kompetensi knseling keluarga sebagai bagian dari multibuadaya, memahami proses advokasi sosial, memahami pola hubungan baik dalam masyarakat ataupun keluarga dan sekolah, memahami proses interaksi interpersonal sosial.

Adanya konseling multibudaya memiliki tujuan tersendiri untuk siswa atau konseli. Tujuan tersebut meliputi muncul dan berkembangnya individu dalam suasana multibudaya, munculnya sikap menghargai antar individu, memiliki sensitifitas budaya, ditemukannya kebutuhan siswa, dan intervensi dari proses konseling (ASCA, 1999). Sensitivitas budaya diperlukan untuk melakukan konseling multibudaya di Indonesia (Nugraha dan Sulistiana, 2017).

Proses interaksi multibudaya yang terjadi disekolah menjadi hal baik untuk setiap siswa.ha tersebut memberikan kesempatan siswa untuk saling memahami budaya dari sekelilingnya agar bisa meminimalisir terjadi konflik antar sesama (Santrock 2007). Konselorpun demikian, konselor bisa belajar dan memahami bagaimana budaya yang ada disekitarnya dan menjadikannya sebagai acuan dalam bersikap ketika melakukan konseling. Dharapkan ketika konseling berlangsung tidak muncul sebuah prasangka.

Prasangka mengarah kepada komponen dari afektif atau emosional dimana bisa menjadi positif atau negatif. Biasanya prasangka akan mengarah kepada penilaian yang negatif. Penyebab dar munculnya prasangka bisa bersumber dari proses berfikir. Individu menangkap apa yang dialihat dan menghubungkannya dengan pengalaman-pengaaman yang sudah dilalui. Ketika pengalaman tersebut negatif maka prasangka akan muncul dan sebaliknya. Konselor sebaiknya menghindari hal ini. Tidak semuanya siswa yang berpenampilan buruk seperti baju tidak dimasukkan tergolong kedalam siswa yang nakal. Begitu pula tidak semua siswa yang berpenampilan baik itu termasuk anak baik. Konselor harus bisa memahami secara untuh bagaimana sisi dari setiap siswa. Baiasanya praangka akan menghampiri konselor diawal proses konseling. Konseli datang kedalam ruang konseling sebagai individu dengan sisinya sendiri yang dilihat oleh konselor. Ketika konselor tidak pernah berurusan dengan siswa tersebut maka konselor harus bisa memperoleh data 
sebanyak-banyaknya terkait diri siswa dan bagaimana budaya dari siswa tersebut. Konselor seharusnya menghindari kegagalan berpikir logis ketika proses konseling karena prasangka negatif diawal perjumpaan dengan konseli.

Kegagalan berpikir logis (the failure of logic) terjadi ketika kemampuan berpikir (logika) individu dikalahkan dengan sisi emosional. Sehingga menurut Purwasito (2003) prasangka lebih cenderung menimbulkan kesalahpahaman daripada kesepahaman berkomunikasi (dalam Sihabudin \& Amiruddin, 2008 ). Prasangka menghampiri setiap jenjang individu. Tidak hanya lingkup sekolah tapi lingkup mahasiswa diperguruan tinggi juga terjadi permasalahan seputar prasangka. Seperti halnya penelitian dari Santhoso dan Hakim (2012) yang memaparkan kondisi deprivasi relatif dan prasangka antar kelompok diperguruan tinggi.

Perspektif konstruktivistik yang memandang pengetahuan berasal dari konstruksi manusia sendiri memberikan gambaran terhadap isu yang ada dalam konseling multibudaya. Konselor harus terlebih dahulu mempelajari suatu budaya dan nilai-nilai budaya tersebut sebelum mencoba untuk mengadaptasi teori bagi konseli tertentu. Pedersen (dalam Gladding, 2015) menjelaskan bahwa konselor harus sensitive terhadap beberapa hal dalam isu budaya yakni:

1. Pengetahuan akan cara pandang konseli yang berbeda budaya

2. Kepekaan terhadap cara pandang pribadi seseorang dan bagaimana seseorang merupakan produk dari pengkondisian budaya

3. Keahlian yang diperlukan untuk bekerja dengan konseli yang berbeda budaya

Unsur objektivitas dari konselor terhadap konseli sangat diperlukan. Konselor perlu untuk menyamakan persepsi terhadap beberapa hal yang menjadi dasar budaya konseli. Ketika persamaan persepsi sudah bisa didapatkan maka konseling akan berjalan dengan sesuai yang diinginkan.

Dari hasil praktek konseling multibudaya yang dilakukan mahasiswa di lapangan ketika magang diperleh gambaran tantangan mereka ketika melakukan konseling multibudaya. Subjek NM menjelaskan bahwa ketika dia melakukan konseling pertama kali, yang muncul adalah rasa khawatir ketidakmampuannya dalam menyelesaikan masalah konseli sehngga subjek harus berusaha engan sungguh-sungguh mendengarkan apa yang disampaikan konseli. Subjek FK menjelaskan bahwa ketika dia melakukan konseling pertama kali yang muncul adalah prasangka negatif terhadap penampilan konseli. Konseli datang dengan penampilan yang tidak rapi sehingga konselor memiliki prasangka konseli merupakan siswa yang sering bermasalah.

Subjek KL menjelaskan ketika pertama kali melakukan konseling yang terjadi adalah prasangka terhadap kondisi konseli. Konseli datang dengan kondisi menangis dan dipikiran konselor yang muncul adalah kekhawatiran tidak bisa membuat tenang konseli. Subjek LM memaparkan kesulitannya ketika melakukan konseling pertama kali yakni prasangka-prasangka banyak muncul ketika proses konseling sehingga konselor harus memikirkan terlebih dahulu terkait teknik konseling yang akan digunakan sehingga mengganggu proses konseling yang dijalaninya. Beberapa pengalaman konseling multibudaya yang dilakukan subjek menjelaskan bahwa prasangka muncul ketika mereka pertama kali melakukan konseling sehingga mereka tertantang untuk lebih belajar mengatur pikiran mereka agar prasangka tidak mengganggu jalannya konseling yang dilakukan. 
Konselor bisa mengadopsi beberapa karakteristik konselor multibudaya dari beberapa sumber. Salah satunya yakni karakter ideal konselor multibudaya ang diadopsi dari nilai luhur semar yakni (1) religius; (2) netral; (3) toleransi; (4) tulus; (5) disiplin; (6) peduli sosial; (7) bersahabat; (8) adil; (9) jujur; (10) luwes; (11) demokratis; dan (12) rasa ingin tahu (Setyaputri, 2017). Pengadopsian tersebut akan menghasilkan proses konseling multibudaya yang optimal jika ditambah dengan hubungan atau relasi yang baik untuk saling memahami antara konselor dan konseli (Nuzliah, 2016). Sehingga, konseling multibudaya juga bisa digunakan untuk anak berkebutuhan khusus (Miskanik, 2018).

\section{KESIMPULAN}

Prasangka menjadi bagian ketika konselor melakukan koseling terutama dalam konseling multibudaya. Hal tersebut terjadi karena perbedaan latar belakang dari diri konselor maupun konseli. Konselor haruslah tetap mengutamakan kemampuan mendengarkan untuk bisa memahami masalah konseli dan fokus dengan apa yang disampaikan konseli ketika melakukan konseling.

\section{DAFTAR RUJUKAN}

ABKIN. (2007). Rambu-rambu Penyelenggaraan Bimbingan dan Konseling ddalam Jalur Pendidikan Formal. Bandung

American School Counselor Asociation. (1999) Position Statement: Multiculturan Counseling. Alexandria, VA: Author

Abimanyu, S., dkk.(2008). Strategi Pembelajaran. Jakarta: Direktoral Jendral Pendidikan Tinggi Departemen Pendidikan Nasional

Dollarhide, T, dkk. (2008). Comprehensifve School Counseling Programs. New York: Perarson Education, Inc

Gladding, S. (2015). Konseling Profesi yang Menyeluruh. Jakarta: PT Indeks

Hogg, A., \& Vaughan, G. M. (2002). Social Psychology (3rd edition). London: Prentice Hall

Nugraha, A., dan Sulistiana, D. (2017). Kepekaan Multibudaya Bagi Konselor dalam Layanan Konseling. Jurnal of Innovation Counseling: Theory, Pratice, \& Reaserch. 1 (1), 9-18

Nuzliah. (2016). Counseling Multikultural. Jurnal Edukasi. 2 (2), 201-214

Miskanik. (2018). Penggunaan Konseling Multikultural dalam Mendorong Perkembangan Kepribadian Anak Berkebutuhan Khusus (ABK). Jurnal Sosio E-Kons. 10 (3). 279-29 

Pederson, P. B., dkk. (2002). Multicultural awareness as a generic competence for counseling. In P. B. Pedersen, J. G

Santhoso, F. H., Hakim, M. A. (2012). Deprivasi Relatif dan Prasangka Antar Kelompok. Jurnal Psikologi. 39 (1), 121-128

Santrock, J. W. (2007). Psikologi Pendidikan. Jakarrta: Fajar Interpratana Offset.

Setyaputri, N. Y. (2017). Karakter Ideal Konselor Multibudaya Berdasarkan Nilai Luhur Semar. Jurnal Kajian Bimbingan dan Konseling. 2 (2), 58-65

Sihabudin , A., Amiruddin S. (2008). Prasangka Sosial dan Efektivitas Komuniakassi Antarkelompok. Mediator. 9(1), 201-219

Sue, dkk. (1996). A Theory of Multikultural Counseling \& Therapy. Pacific drove: Books/cole 